УДК 330.341.1

DOI: $10.31673 / 2415-8089.2019 .033541$

Гужавіна І.В., к.е.н., доц.; Дименко Р.А., к.е.н.;

Лобань О.O.

Державний університет телекомунікацій

\title{
ЕКОНОМІКО-ПРАВОВІ АСПЕКТИ ВПРОВАДЖЕННЯ ІННОВАЦІЙ НА ПІДПРИЕМСТВАХ
}

\begin{abstract}
Розглянуто роль інновачій в діяльності сучасного підприємства. Наведено класифікацію витрат на інновачії для забезпечення правильного обчислення реальної собівартості продукиї та ії аналізу. Визначено механізм розрахунку рівня інновачійної активності підприємства. Запропоновано иляхи оцінки ефективності інноваџій за рахунок визначення показників виробничої ефективності, фінансової ефективності, інновачійної ефективності.
\end{abstract}

Ключові слова: інновація, інновачійний процес, витрати підприємства, інноваційна діяльність, інноваційна активність.

Постановка проблеми. В економіці країн світу, включно з Україною, підприємства $\epsilon$ основними ланками, що визначають рівень соціально-економічного розвитку, соціальну i економічну безпеку, якість життя населення. Разом з тим слід зазначити, що торгівельні підприємства - один з секторів економіки, який сильно підпадає під вплив економічних циклів кон'юнктури і конкурентної боротьби на ринках. Саме тому впровадження інновацій розглядається як найважливіший фактор конкурентоздатності підприємства, фірми i, в рештірешт країни.

Аналіз останніх досліджень і публікацій. Питання інновацій, інноваційного розвитку підприємств є предметом дослідження багатьох вчених-економістів, які розглядають різні аспекти інновацій залежно від підходів у трактуванні їх суті та розвитку підприємств на основі впровадження інновацій. Методологічні засади щодо формування поняття інновації визначені в наукових працях зарубіжних і вітчизняних вчених, серед яких: Б. Санто, І. Буднікевич, П. Микитюк, В. Мединський, М. Денисенко, Г. Цадо, С. Степова, Ж. Крисько, Р. Квасницька, А. Гриньова, С. Ілляшенко, Н. Маренкова, Ю. Морозова, А. Пилипенко, М. Полегенька, Ю. Цал-Цалко та інші. Однак, незважаючи на велику кількість досліджень, на сьогодні не існує єдиного підходу до розуміння сучасного змісту цього поняття «інновації». Враховуючи швидкоплинність економічних процесів залишаються дискусійними та потребують подальших досліджень багато аспектів визначення інновації як економічної категорії, а також необхідності впровадження інновацій на підприємствах.

Мета статті полягає в визначенні економіко-правових аспектів впровадження інновацій на підприємствах.

Визначення поняття «інновація» на державному рівні дає Закон України «Про інноваційну діяльність», де інновація розглядається як новостворені (застосовані) i вдосконалені конкурентоспроможні технології, продукція або послуги, а також організаційно-технічні рішення - виробничі, адміністративні, комерційні та інші, що істотно поліпшують структуру та якість виробництва і (або) соціальної сфери [1].

I.B. Буднікевич визначила, що «інновація» - це комплексний процес, спрямований на створення, розроблення чи доведення наукової чи будь-якої іншої наукової ідеї до стадії комерційного використання та поширення в економіці [2].

(С Гужавіна I.В., Дименко Р.А., Лобань О.О., 2019 
За даними Держкомстату України [3, с. 471] за 2017 рік, витрати на інновації в промисловості з року в рік зростають, і якщо загальна сума витрат на інновації у 2010 році становила 8045,5 млн. грн., то в 2017 році обсяг фінансування складає 9117,5 млн. грн., тобто збільшився на 1072 млн. грн. Але основним джерелом фінансування інновацій залишаються власні кошти підприємств, в 2010 році вони складають 59,4\%, а в 2017 році - 84,5\%. Суттєвим недоліком є скорочення фінансування інновацій з боку іноземних держав, якщо в 2010 році питома вага фінансування складає 30\%, то в 2017 році - 1,2\%.

Незважаючи на прийняту низку законодавчих актів, що стосуються розвитку i впровадження інноваційних процесів та створеного у 2005 році спеціального «Державного агентства 3 інвестицій та інновацій», в 2010 році це агентство перетворено в «Державне агентство України 3 інвестицій та розвитку», яке повинно вирішувати проблеми, що виникають на всіх етапах інноваційних та інвестиційних проектів, впровадження інновацій в Україні залишається на низькому рівні.

Для успішного функціонування сучасному підприємству на глобальному ринку, який характеризується безперервним посиленням конкуренції, підприємству необхідно, по-перше, планувати, контролювати і оптимізувати свої витрати на всьому економічному ланцюжку та, по-друге, разом 3 іншими учасниками вміти управляти та регулювати цими витратами й прагнути оптимізації кінцевого результату [4]. Вартісний ланцюжок витрат підприємства 3 позиції стратегічного управління має вигляд (рис. 1).

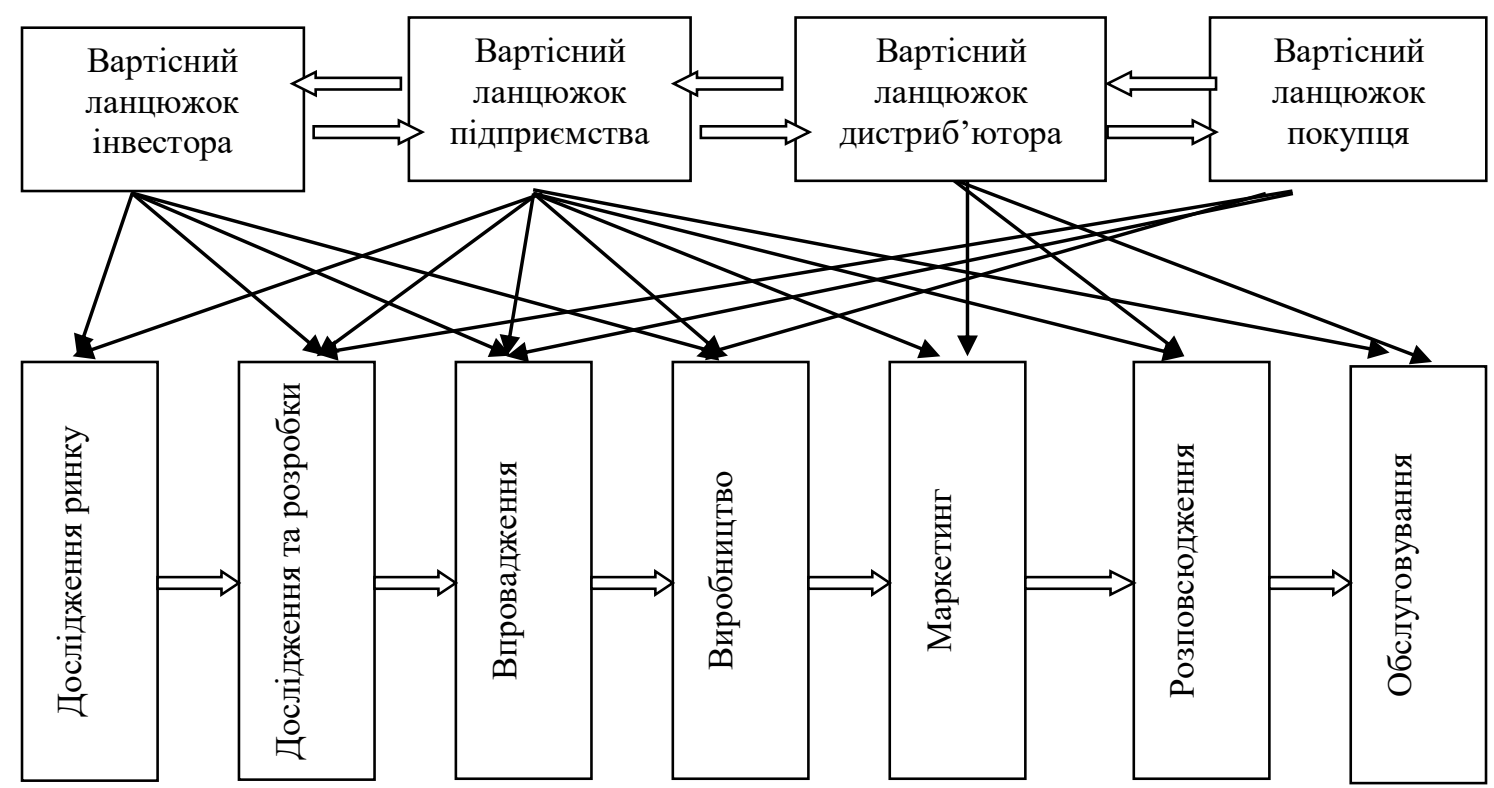

Рис. 1. Вартісний ланцюжок витрат підприємства з позиції стратегічного управління

За даними рис. 1, можна зробити висновок, що частина витрат, 3 точки зору стратегічного управління, може бути контрольована і іншими учасниками впровадження інноваційного процесу, що обов'язково потрібно враховувати. Тому сьогодні бізнес дедалі частіше переходить від обчислення витрат тільки власної внутрішньої діяльності до калькуляції всього економічного процесу, в якому підприємство являє собою лише одну ланку.

Досліджуючи об'єкти обліку інноваційного процесу підприємства не можна ігнорувати важливий метод пізнання - класифікацію витрат на інновації. Класифікація витрат $є$ базою для побудови як синтетичного, так і аналітичного обліку витрат на інновації, обгрунтованого й своєчасного контролю, правильного обчислення реальної собівартості продукції та іiї аналізу. 
Критичний аналіз літературних джерел показав, що немає єдиної установленої класифікації витрат на інновації [5, с. 15]. Дослідження особливостей діяльності підприємства дозволило визначити класифікацію витрат на інновації на основі конкретних ознак, що адекватно відображають їх сутність (табл. 1).

Таблиця 1

Класифікація витрат підприємства на інновації

\begin{tabular}{|c|c|c|}
\hline Класифікаційна ознака & Види витрат & $\begin{array}{c}\text { Сфера застосування обліково- } \\
\text { аналітичної інформації }\end{array}$ \\
\hline За періодичністю виникнення & Разові, періодичні, поточні & Прийняття рішень \\
\hline $\begin{array}{l}\text { За оцінкою ефективності } \\
\text { прийняття рішень }\end{array}$ & Дійсні та альтернативні & Аналіз та контроль \\
\hline $\begin{array}{l}\text { За цільовим спрямуванням } \\
\text { науково-технологічного } \\
\text { процесу }\end{array}$ & $\begin{array}{l}\text { Впровадження нового } \\
\text { технології, матеріалів, } \\
\text { готової продукції }\end{array}$ & Прийняття рішень \\
\hline За характером робіт & \begin{tabular}{llr} 
Виконання & \multicolumn{2}{c}{ організаційно- } \\
технологічних робіт, підготовка та \\
освоєння виробництва
\end{tabular} & Прийняття рішень \\
\hline За джерелами фінансування & $\begin{array}{l}\text { Власні кошти, кредити банків, } \\
\text { бюджетні кошти, цільові пайові } \\
\text { внески інших юридичних і фізичних } \\
\text { осіб, іноземні інвестиції }\end{array}$ & Прийняття рішень \\
\hline $\begin{array}{l}\text { За стадіями відтворювального } \\
\text { процесу }\end{array}$ & $\begin{array}{l}\begin{array}{l}\text { Підготовка } \\
\text { експлуатація }\end{array}, \text { виробництво, обіг, } \\
\end{array}$ & $\begin{array}{l}\text { Прийняття рішень } \\
\text { Аналіз та контроль }\end{array}$ \\
\hline $\begin{array}{l}\text { За методом включення } \\
\text { собівартість проекту }\end{array}$ & Прямі і непрямі & Визначення вартості продукту \\
\hline $\begin{array}{l}\text { За можливістю внесення змін } \\
\text { в собівартість проекту }\end{array}$ & Релевантні, не релевантні & $\begin{array}{l}\text { Аналіз } \\
\text { Прийняття рішень }\end{array}$ \\
\hline $\begin{array}{lr}\text { За } & \text { ступенем } \\
\text { контрольованості } & \text { в центрах } \\
\text { відповідальності } & \\
\end{array}$ & Контрольовані, неконтрольовані & Аналіз та контроль \\
\hline $\begin{array}{l}\text { За центрами виникнення } \\
\text { витрат }\end{array}$ & Робочі місця, цехи. & $\begin{array}{l}\text { Прийняття рішень } \\
\text { Аналіз та контроль }\end{array}$ \\
\hline За способом розподілу & Основні, накладні & Визначення вартості продукту \\
\hline \multirow{2}{*}{$\begin{array}{l}\text { За способом } \\
\text { відтворювання }\end{array}$} & Вичерпні, невичерпні & Аналіз \\
\hline & & Прийняття рішень \\
\hline За методом групування & $\begin{array}{l}\text { За статтями калькуляції. } \\
\text { За економічними елементами }\end{array}$ & Визначення вартості продукту \\
\hline $\begin{array}{l}\text { За методом оптимізації } \\
\text { величини прибутку }\end{array}$ & $\begin{array}{l}\begin{array}{l}\text { Витрати на продукцію та витрати } \\
\text { періоду }\end{array} \\
\end{array}$ & Визначення вартості продукту \\
\hline За характером витрат & Поточні і капітальні & Прийняття рішень \\
\hline
\end{tabular}

Наведена класифікація витрат на інновації, інформаційно та обліково-аналітично забезпечує весь життєвий цикл інноваційного процесу - від початку до завершення та найбільш повно характеризує види витрат, що можуть бути понесені при виконанні інноваційного проекту.

Застосування сучасних програмних продуктів вносить значні зміни в організацію документування, які полягають, по-перше, у використанні електронних носіїв первинної інформації і електронних первинних документів i, по-друге, в автоматичному складанні первинних документів. Діяльність підприємства перетворює інформацію в документ, але документ припиняє існування, якщо в подальшому над ним не будуть здійснені процедури обробки.

Вимоги до організації документування виконання інноваційного проекту в умовах автоматизації обліку включають в себе наступні етапи:

1. Виявлення та реєстрація всієї первинної облікової інформації щодо виконання конкретного інноваційного проекту.

2. Документування всієї зареєстрованої первинної облікової інформації. 
3. Перевірка правильності і достовірності зареєстрованої в документі первинної інформації.

4. Обробка, систематизація інформації та своєчасна передача іiі зовнішнім і внутрішнім користувачам.

5. Можливість перевірки у встановленому порядку виконання перерахованих вище вимог.

6. Можливість використання інформації для прийняття послідуючих управлінських рішень щодо впровадження нових інноваційних проектів.

Сутність поняття інноваційного потенціалу визначається як сукупність виробничих, наукових, фінансових, маркетингових, кадрових, організаційних ресурсів і можливостей, що забезпечують готовність і здатність підприємства здійснювати інноваційну діяльність при постійному удосконалені системи управління нею з урахуванням факторів нестабільності ринкового середовища.

Слід відзначити, що в ході проведення діагностики інноваційного потенціалу підприємства виникає низка проблем. Основна проблема пов'язана 3 недостатністю необхідної аналітичної інформації, що ускладнює діагностику інноваційного потенціалу та проблемністю оцінки окремих елементів інноваційного потенціалу коли іiі неможливо здійснити кількісно. В цьому випадку застосовується метод експертних оцінок, який базується на суб'єктивних думках експертів [5, с. 15-16].

Бальна оцінка використання підприємством кожного 3 складових елементів інноваційного потенціалу здійснюється 3 використанням шкали від 1 до 3 . Важливо враховувати вплив ризиків, які зменшують рівень інноваційної активності та не дозволяють в повній мірі використати інноваційний потенціал підприємства. Застосування відповідних антиризикових процедур, підприємство зменшує їх вплив і тим самим коефіцієнт загального рівня інноваційної активності наближається до одиниці.

Рівень інноваційної активності підприємства визначається як добуток коефіцієнта ваги елемента на бальну оцінку його використання.

Бальна оцінка використання підприємством елементів інноваційного потенціалу представлена в табл. 2.

Таблиця 2

Оцінка стану елементів інноваційного потенціалу умовного підприсмства

\begin{tabular}{|c|c|c|c|c|}
\hline Складові & Параметри & $\begin{array}{l}\text { Коефіцієнт } \\
\text { вагомості }\end{array}$ & Бали & $\begin{array}{c}\text { Зважена } \\
\text { Оцінка }\end{array}$ \\
\hline 1 & 2 & 3 & 4 & 5 \\
\hline $\begin{array}{l}\text { 1. Організаційний } \\
\text { потенціал }\end{array}$ & $\begin{array}{l}\text { 1.1. Ступінь інноваційної спрямованості } \\
\text { організаційної структури } \\
\text { 1.2.Рівень відповідності організаційної } \\
\text { культури інноваційному розвитку } \\
\text { підприємства } \\
\text { 1.3.Рівень компетенції керівників } \\
\text { 1.4.Розвиненість системи інформаційного } \\
\text { забезпечення }\end{array}$ & & $\begin{array}{l}2 \\
2 \\
2\end{array}$ & \\
\hline Підсумкова оцінка & & 0,15 & 9 & 1,35 \\
\hline $\begin{array}{l}2 . \\
\text { потенціал }\end{array}$ & $\begin{array}{l}\text { 2.1. Рівень кваліфікації персоналу } \\
\text { 2.2. Ступінь готовності персоналу до змін } \\
\text { на підприємстві } \\
\text { 2.3. Розвиненість системи мотивації } \\
\text { персоналу } \\
\text { 2.4. Ступінь творчої ініціативності }\end{array}$ & & $\begin{array}{l}2 \\
2 \\
1 \\
2\end{array}$ & \\
\hline
\end{tabular}




\begin{tabular}{|c|c|c|c|c|}
\hline & персоналу & & & \\
\hline Підсумкова оцінка & & 0,25 & 7 & 1,75 \\
\hline $\begin{array}{l}\text { 3.Науково-технічний } \\
\text { потенціал }\end{array}$ & $\begin{array}{l}\text { 3.1. Рівень витрат на наукові дослідження } \\
\text { i розробки } \\
\text { 3.3. Частка персоналу, який займається } \\
\text { науковими розробками }\end{array}$ & & 3 & \\
\hline Підсумкова оцінка & & 0,15 & 6 & 0,90 \\
\hline $\begin{array}{l}4 . \quad \text { Виробничий } \\
\text { потенціал }\end{array}$ & $\begin{array}{l}\text { 4.1. Ступінь використання виробничої } \\
\text { потужності } \\
\text { 4.2. Ступінь гнучкості виробництва } \\
\end{array}$ & & 2 & \\
\hline Підсумкова оцінка & & 0,10 & 4 & 0,40 \\
\hline $\begin{array}{l}\text { 5. Маркетинговий } \\
\text { потенціал }\end{array}$ & \begin{tabular}{|l|} 
5.1.Раціональність використання каналів \\
розповсюдження послуг \\
5.2. Гнучкість цінової політики \\
5.3. Рівень використання реклами \\
5.4. Ефективність системи реалізації \\
\end{tabular} & & $\begin{array}{l}2 \\
1 \\
2\end{array}$ & \\
\hline Підсумкова оцінка & & 0,10 & 7 & 0,70 \\
\hline $\begin{array}{l}6 . \quad \text { Фінансовий } \\
\text { потенціал }\end{array}$ & $\begin{array}{l}\text { 6.1. Коефіцієнт абсолютної ліквідності } \\
\text { 6.2. Коефіцієнт швидкої ліквідності } \\
\text { 6.3. Коефіцієнт оборотності активів } \\
\text { 6.4. Фінансова стійкість підприємства }\end{array}$ & & $\begin{array}{l}1 \\
1 \\
2 \\
2\end{array}$ & \\
\hline Підсумкова оцінка & & 0,10 & 6 & 0,60 \\
\hline \begin{tabular}{|lc}
7. & Потенціал \\
енергозбереження
\end{tabular} & $\begin{array}{l}\text { 7.1. Залучення до співпраці науковців та } \\
\text { експертів } \\
\text { 7.2. Рівень застосування прогресивних } \\
\text { енергозберігаючих технологій } \\
\text { 7.3.Проведення заходів } 3 \text { охорони } \\
\text { довкілля }\end{array}$ & & 2 & \\
\hline Підсумкова оцінка & & 0,15 & 4 & 0,60 \\
\hline $\begin{array}{l}\text { 8. Вплив } \\
\text { ризиків }\end{array}$ & $\begin{array}{l}\text { 8.1. Внутрішні ризики: } \\
\text { - подолані } \\
\text { - не подолані } \\
\text { 8.2. Зовнішні ризики: } \\
\text { - соціально-економічні }\end{array}$ & & $\begin{array}{l}1 \\
3\end{array}$ & \\
\hline & - політичні & & 2 & \\
\hline \multicolumn{2}{|l|}{ Підсумкова оцінка } & $-0,15$ & 8 & $-1,2$ \\
\hline \multicolumn{2}{|c|}{ Загальний рівень інноваційного потенціалу } & 0,85 & $\mathrm{x}$ & 5,10 \\
\hline
\end{tabular}

Чим вищим є рівень використання складових елементів інноваційного потенціалу, тим більше у підприємства конкурентних переваг для здійснення ефективної інноваційної діяльності [5, с. 16]. Оцінку рівня інноваційної активності підприємства доцільно здійснювати за наступною шкалою: до 3,0 - низький рівень, від 3,0 - до 6,0 - середній рівень, більше 6,0- високий рівень. На основі проведеної оцінки, рівень інноваційної активності підприємства оцінюється в 5,10 бали, що свідчить про сукупний середній рівень використання інноваційних можливостей підприємства.

Ефективне управління підприємством залежить значною мірою від розвиненості системи обліку та ступеня іiі комп'ютеризації. Вимогам ринкової економіки найбільшою мірою відповідає форма обліку, орієнтована на широке використання мереж ПЕОМ [6, с. 226].

Слід зазначити, що кінцевим результатом впровадження інновацій на підприємстві $є$ збільшення прибутку. Для оцінювання ефективності інновацій на рівні підприємства 
застосовують широку систему показників, які можна об'єднати у три групи: виробнича ефективність (економія від зниження собівартості продукції; скорочення витрат праці на виробництво продукції; приріст споживчої цінності продукції; здатність заощаджувати та зберігати енергію); фінансова ефективність (приріст доданої вартості за рахунок інновації; приріст доходу за рахунок застосування інновації; приріст прибутку за рахунок застосування інновацій); інвестиційна ефективність (норма доходності, індекс рентабельності інвестицій в інноваційний проект; дисконтований термін окупності інвестицій в інноваційний проект)

Висновки. Ринкові умови господарювання створюють для суб'єктів економіки високий рівень конкурентних відносин, у яких виграє той, на чийому боці конкурентні переваги у сфері виробництва і реалізації товарів. Впровадження інновацій розглядається як найважливіший фактор конкурентоздатності підприємства.

Для досягнення поставленої мети підприємству необхідно планувати, контролювати i оптимізувати свої витрати на всьому економічному ланцюжку та разом з іншими учасниками вміти управляти та регулювати цими витратами й прагнути оптимізації кінцевого результату. Оцінити рівень інноваційної активності підприємства можна 3 допомогою системи коефіцієнтів, а також розповсюдженою $є$ методика бальною оцінки стану інноваційного потенціалу підприємства. Впровадження на підприємствах зазначених заходів дозволяє підприємству не тільки оцінити свій інноваційний потенціал, але й визначити свої конкурентні переваги. Значущість зазначених питань потребує також проведення подальших досліджень щодо впровадження інновацій на підприємствах.

\section{Список використаної літератури}

1. Про інноваційну діяльність: Закон України від 04.07.2002 р. № 40-IV дата оновлення 16.10.2012. URL: http://zakon3.rada.gov.ua/laws/show/40-15

2. Буднікевич I.M. Становлення регіонального ринку інновацій: теорія та практика (на прикладі Карпатського регіону): дис... канд. екон. наук: 08.10.01. / Чернівецький національний ун-т ім. Юрія Федьковича, Чернівці, 2002. 239 с.

3. Статистичний щорічник України за 2017 рік. Державний комітет статистики України / під ред. І. Є. Вернера; відпов. за випуск О. А. Вишневська. Київ: Державна служба статистики України, 2018. 541 с.

4. Ц Цал-Цалко Ю.С. Витрати підприємства: навч. посібник. Київ: ЦУЛ, 2002. 656 с.

5. Шандова Н.В. Методичні аспекти організації управління витратами Фінанси підприємств. 2003. № 7. С. 15-20.

6. Белявцева В.В. Автоматизированные технологии организации управленческого учета в торговле Економіка: проблеми теорї̈ та практики: Зб.наук.пр. Дніпропетровськ: Наука $\mathrm{i}$ освіта. 2005. Вип. 206. С. 224-229.

\section{REFERENCES}

1. Pro innovatsiynu diyalnist: Zakon Ukrainy 2002, № 40 IV $\S$ rozdil 1 stattia 1 . Retrieved from http://zakon3.rada.gov.ua/laws/show/40 15

2. Budnikevich, I.M. (2002). Stanovlennya regionalnogo rinku innovatsiy: teoriya ta praktika (na prikladi Karpatskogo regionu) [Becoming a Regional Innovation Market: Theory and Practice (on the example of the Carpathian region) (Candidate dissertation). Chernivtsi: Chernivtsi National University named after Yuriy Fedkovich.

3. Verner, I.E. (2018) Statistichniy shchorichnik Ukraïni za 2017 rik. Kyiv: State Statistics Service of Ukraine.

4. Tsal-Tsalko, Y.S. (2002) Vitrati pidpriemstva [Costs of the enterprise] Kyiv: Educational literature center. 
5. Shandova, N.V. (2003) Metodichni aspekti organizatsiï upravlinnya vitratami [Methodical aspects of organization of expenditure management finance of enterprises]. Business finance, (7), $15-20$.

6. Belyavtseva, V.V. (2005) Avtomatizirovannye tekhnologii organizatsii upravlencheskogo ucheta $\mathrm{v}$ torgovle [Automated technologies of organization accounting management in trade]. Economics: problems of theory and practice: Science and education, (206), 224-229.

\begin{abstract}
ГУЖАВИНА ИННА ВАСИЛЬЕВНА, ДЫМЕНКО РУСЛАН АНАТОЛЬЕВИЧ, ЛОБАНЬ ОЛЬГА АЛЕКСАНДРОВНА. ЭКОНОМИКО-ПРАВОВЫЕ АСПЕКТЫ ВНЕДРЕНИЯ ИННОВАЦИЙ НА ПРЕДПРИЯТИЯХ. Рассмотрена роль инновачий $в$ деятельности современного предприятия. Приведена классификаџия затрат на инноваџии для обеспечения правильного расчета реальной себестоимости продукции и ее анализа. Определен механизм расчета уровня инновационной активности предприятия. Предложень пути оценки эффективности инноваций путем расчета показателей производственной эффективности, финансовой эффективности, инновационной эффективности.
\end{abstract}

Ключевые слова: инновачия, инновачионный процесс, расходы предприятия, инновационная деятельность, инновационная активность.

HUZHAVINA INA, DYMENKO RUSLAN, LOBAN OLGA. LEGAL AND ECONOMIC ASPECTS OF INNOVATION. The role of innovations in the modern enterprise activities is viewed. The classification of innovation costs is provided to ensure the correct calculation of the real cost of production and its analysis. The determination of the innovation activity levels calculation is given. The ways of estimation of the innovation efficiency at the expense of definition of indicators of production efficiency, financial efficiency, innovative efficiency are provided.

Key words: innovation, innovation process, enterprise expenses, innovation activity, innovation activities. 